\title{
The European Council and the Legitimacy Paradox of New Intergovernmentalism: Constitutional Agency Meets Politicization
}

\author{
Andrew Glencross \\ University of Stirling \\ Division of History and Politics \\ Stirling, FK8 2LB \\ andrew.glencross@stir.ac.uk
}

\section{ABSTRACT}

This paper examines the actions of the European Council during the Eurozone crisis through the lens of political constitutionalism. This analysis examines the role of political inputs in shaping EU constitutional developments, whether supranational or intergovernmental, to demonstrate the "legitimacy paradox" of new intergovernmentalism. That is, the European Council claimed the electoral legitimacy to rescue the Euro, but in doing so opened up new avenues for contesting EU legitimacy, notably in relation to national budgetary decision-making. For unlike with supranational constitutional agency, the European Council has the means to politicize its actions. However, the strategy taken during the sovereign debt crisis is shown to be one of depoliticization to prevent domestic contestation of EMU reform. At the same time, paradoxically, the politics of macro-economic policy has become Europeanized with the active participation of EU supranational actors. Since EMU reform is dependent on supranational enforcement of EMU rules, the new intergovernmentalism faces political contestation that previous, supranational EU constitutional development did not. 
Key Words: Political Constitutionalism, new intergovernmentalism, legitimacy, Eurozone crisis, politicization, supranationalism, 


\section{Introduction}

This article expands the discussion of constitutional practices in the EU treated in this special issue by applying the theoretical lens of political constitutionalism (Bellamy 2007; Goldoni 2012) to capture overlooked features of the EU's legal-political development under the aegis of the European Council. The objective is to respond to what the editors of this special issue have termed the need for a 'new political theory of the legitimacy of intergovernmental institutions' (Fabbrini and Puetter, introductory article of this special issue). This imperative stems from the "integration paradox" identified by Puetter (2012), whereby ever closer union is being forged through intergovernmental action, not supranationalism. However, at the same time as the heads of State and Government have claimed the electoral legitimacy to rescue the Euro, the resulting reforms, I claim, are prone to engender more contestation and supranational politicization. This leads to a situation dubbed here as the "legitimacy paradox" of new intergovernmentalism.

In analysing the causes and consequences of this legitimacy paradox it is important to recall the meaning of intergovernmentalism, which is premised on the existence of its antonym, supranationalism. These terms suggest a binary logic in the European integration process, a dichotomy that holds true, following Fabbrini (2013), for two constitutional logics: a supranational form (associated with supranational agents such as the CJEU or a constitutional convention) or an intergovernmental variant manifested by diplomatic wrangling over treaty change. Separating out constitutional logics in this manner captures the peculiar dynamics of EU integration since the Maastricht treaty (ibid.). As part of these developments, it is necessary to focus on how the EU's particular brand of dual constitutionalism has evolved politically, beyond formal black-letter legal intricacies (Bellamy 2007). A political reading of constitutionalism regards constitutional rules and practices as the product of political actors participating in an on-going development; the actors involved (courts, elected officials, parties, and citizens), are constitutional agents taking part in constitutional agency (Goldoni and McCorkindale 2013). 
Consequently, this article assesses the role of political inputs (elections, direct democracy, and popular mobilization) in shaping treaty-related constitutional developments that give rise to the legitimacy paradox. What matters for this analysis is not just the source of actors' authority - national or EU-wide - but also the kind of political contestation that surrounds the constitutional evolution they set in motion. This framing of the political nature of constitutionalism thus requires an appreciation of the politicization surrounding constitutional agency within the EU, with politicization taken to mean making constitutional development a subject of public discussion and contestation (de Wilde and Zürn 2012). Such a move makes possible a comparison between the recent constitutional agency of the European Council and previous fundamental changes in the EU's constitutional order. Hence the focus is on comparing the politicization of integration as it occurs across different forms of constitutional change; the paper does not address the wider phenomenon of how the EU is contested in national fora.

This contrast, developed in section one, demonstrates that in the course of European integration there have been three types of constitutional agency relating to change in the content or interpretation of the treaties. Each involved varying degrees of politicization based on the institutional opportunity structure each type of agency offers for contesting the creation of EU constitutional rules and their enforcement. Supranational forms of constitutional agency via judicial intervention and the convention method respectively have involved low levels of politicization. In the case of the former this was structural and deliberate as courts are non-majoritarian institutions par excellence. The convention method was intended to allow for open and public debate, yet these ambitions never materialized. The third type is that of intergovernmental constitutional agency involving members of the European Council. In such instances the difference is that the European Council has certain political levers - activated by individual leaders or also collectively - to politicize or depoliticize constitutional rulemaking and enforcement.

The argument then proceeds, in section two, by analyzing the political contestation surrounding the recent constitutional agency of the European Council. The intergovernmental solutions decided upon by the European Council to fix the sovereign debt crisis are shown to have been 
accompanied by a strategy of depoliticization. That is, heads of state and government sought to prevent contestation that might delay overhauling EMU or put into question the nature of how bailout settlements are negotiated. In this way the new intergovernmentalism (Bickerton et al. 2014) is associated with a form of constitutional agency that, from a political constitutionalism perspective, is inherently contradictory. National leaders claim a democratic mandate to resolve EU crises in lieu of supranational agency, whilst at the same time stymying democratic contestation of emergency measures within and across member states.

Section three shows how this legitimacy paradox is accompanied by increased political contestation of the Europeanized system of rule implementation concerning the macro-economic policy of Eurozone countries. Leaders and parties have little alternative except to challenge rule enforcement following fundamental, intergovernmentally negotiated and depoliticized rule change. The overall result is to show that the EU in its new intergovernmental phase still lacks a form of political constitutionalism that can legitimize constitutional agency - just as it did during the heyday of supranationalism. The key difference is that intergovernmental constitutional agency now faces the kind of contestation that previous, supranational EU constitutional development did not.

\section{Three Types of Constitutional Agency in European Integration}

In the course of the highly successful constitutionalization of European integration (Weiler, 1991; Stone Sweet, 2004) three types of constitutional agency can be identified. That is, the impetus for fundamental constitutive change can be traced to different actors and associated processes that have shaped the contours of EU competences and decision-making rules. The establishment of a constitutional-like structure has proceeded in one of three different ways: through judicial intervention, via special conventions, and diplomatically through inter-elite negotiation. It is within this context of different forms of constitutional agency that the contribution of the new intergovernmentalism exercised during the Eurozone crisis needs to be situated before its distinctiveness can be scrutinized properly.

The contribution of the CJEU and national courts to integration through law is well-documented. It was the former's jurisprudence in key cases 
during the 1960s, accepted and even sought after by a range of national courts, that paved the way for a binding system of EU law in a way that the original EEC member states had not anticipated (Weiler 1991). These judicial interventions had long-lasting political repercussions, even if governments did not feel their effects immediately as the CJEU was strategic in confronting doctrinal questions using a long time horizon (Alter 1998). More fundamentally, this revolutionary jurisprudence was articulated in a supranational manner beyond the gaze and the control of national political actors (or popular mobilization).

Diplomatic negotiation is a more visible and immediate form of constitutional agency than abstruse legal reasoning. At various junctures in the process of "ever closer union" member states have sat down at an intergovernmental conference (IGC) to thrash out new treaties or to revise the existing ones. Such negotiations are complex, fraught affairs that invariably raise questions about national preference formation (Moravcsik 1998). Hence this kind of diplomatic horse-trading can become highly politicized within national politics, particularly in subsequent ratification processes that are conducted according to diverse national practices including referendums. Indeed, there was an attempt to link the 2005 Constitutional Treaty to a series of national ratification-by-referendum procedures but this project was derailed by the rejection of the treaty in popular votes held in France and the Netherlands. Thus it is impossible to speak of a standalone category of constitutional agency via direct democracy, unlike what happens in Switzerland where referendums can provide a vehicle for popular mobilization to contest and settle constitutional issues (Glencross 2014a).

A third form of constitutional agency was attempted by means of specially constituted "conventions" designed to bring together a wider cast of stakeholders than would otherwise be present at an IGC. This "convention method" was used to draw up first a Charter of Fundamental Rights and Freedoms (1999-2000) and later to debate the future of Europe (200203). The latter brought together European and national parliamentarians, government representatives, and other political actors to discuss constitutional arrangements suitable for a soon-to-expanded EU. According to one leading law scholar, the 'undoubted attraction of the convention method lies in the way it broadens participation in the 
constitutional conversation and thereby allows a public débat d'idées' (de Witte, 2003: 215). Such an ambition points to the way that conventions were considered a more deliberative and transparent method of constitutional change than either of the other two forms of constitutional agency. As such, this method can certainly be considered more inherently supranational than diplomatic negotiation. For instance, the Convention on the Future of Europe consisted of 105 members, including 16 MEPs and 2 Commissioners alongside national parliamentarians and government representatives for each member state. (Of course, both the Charter and the Draft Constitutional Treaty required intergovernmental agreement to move into the realm of hard law.)

\section{Politicization and the Different Types of Constitutional Agency}

Having identified these three forms of constitutional agency it is now possible to contrast the political dynamics according to how far they establish a "political opportunity structure" for debating and contesting integration (de Wilde and Zürn 2012). Although the increase in EU authority is well known to have raised the saliency of integration within national politics (Hooghe and Marks 2009), political mobilization and contestation over this process has been deliberately muted (Mair 2007). This tendency of depoliticizing the construction of a European Union can be ascribed to elites' willingness to set aside disputes over what form the nascent polity should eventually take in favour of creating a new venue for pursuing policy goals that would be less fettered by domestic constituencies (Hooghe and Marks 2009).

Nevertheless, there is a range of institutional and discursive opportunities available to politicize integration (de Wilde and Zürn 2012). These include national narratives employed to frame membership of the EU, media coverage, competitive party politics, and specific institutional moments such as referendums and crises in which the scope and level of EU integration come to the fore. What matters for present purposes though is how far different types of constitutional agency provide opportunities for the politicization of constitutive change within the EU.

In its judicial guise, constitutional agency proceeds by disempowering national executives and parliaments in favour of an inter-linked national 
and supranational legal superstructure (Alter 1998). Indeed, member states were blindsided by the Luxembourg's court strategic use of the preliminary reference procedure to establish a new legal order as best illustrated perhaps by the 1988 Factortame case in the UK. More than two decades after the CJEU's revolutionary jurisprudence, the British government was surprised that the House of Lords (acting then as Britain's ultimate court of appeal) had the right to strike down legislation that infringed EEC law (MacCormick 1999). Equally important is the fact that integration through law has had a significant impact on policy-making via secondary legislation designed to make the four fundamental freedoms a reality. That is, the reliance on integration via the legal establishment of a pan-European single market, without corresponding social policy competences capable of counteracting inequalities, 'systematically weakens established socio-economic regimes at the national level, and it also generates a liberalizing bias in European legislation' (Scharpf 2010: 243).

These fundamental constitutive changes relating to rule creation and enforcement were wrought - albeit in a drawn-out fashion - by CJEU jurisprudence and took place largely in the absence of politicized debates, popular mobilization or electoral inputs. The agency of the CJEU is thus a classic instance of de-politicized, legal constitutionalism whereby competing rights or competence claims are adjudicated in a nonmajoritarian fashion (Bellamy 2007). It was in part as a reaction to this depoliticized constitutional evolution that a more open and deliberative model of constitutional agency was promoted by way of the "convention method" (Crum 2012).

Conventions were called into being first to discuss individual rights and then to design a blueprint for an expanded and more democratic EU by producing a Draft Constitutional Treaty. This constitutional convention deliberately mimicked the Philadelphia Convention of 1787 that produced the US federal constitution. The hope was to set in motion a politicized constitutional moment that would symbolize what the EU was and stood for, while at the same time tweaking its institutional makeup. The Convention was enacted in a top-down fashion by the European Council that met in Laeken in 2001, with the aim of establishing a body that would generate constitutional reflection in order to make the EU more 
democratic, transparent and effective. The supranational membership of the Convention on the Future of EU, combined with its deliberative working methods, meant it drew on an "ontology of solidarism" in that its participants claimed to stand for a putative European people (Bellamy and Castiglione 2013). In this context, the power of national governments was deliberately set to one side, allowing the Praesidium to benefit greatly in terms of agenda-setting and the ability to supervise the drafting of treaty articles (Kassim 2004).

Nevertheless, the final product of the Convention was picked apart at an IGC, where member states had the job of establishing a final treaty for signature and ratification. Indeed, even before the assembled representatives finalized their text intergovernmental power was in evidence as government representatives negotiated directly with the Praesidium. Perhaps most symbolically, United Kingdom Prime Minister Tony Blair met Convention President Giscard d'Estaing to emphasize the need to expunge the word "federalism" from any final document, a message that was not ignored (ibid.). Although revelatory about the dynamics of power, this anecdote about back-room deals also hints at the level of politicization the Convention method achieved: it was an elitedriven affair that failed to connect with a mass public. Intended to contribute to a broad, pan-European public debate, this process for revising the treaties gave rise instead to inward-looking and selfjustificatory tendencies (Crum 2012).

This disconnect with ordinary voters helps explain why the EU's political elite was so startled by voters' rejection of the Constitutional Treaty in the Netherlands and France. National politicians were unprepared for the kind of politicization, which became entangled with tangential issues such as fear of service competition (the Polish plumber), Turkish accession, secularism, and abortion rights, that suddenly surrounded debates on the Constitutional Treaty in those countries (Maatsch 2007). Politicization took place domestically, therefore, but only after national publics were specifically called upon by certain governments to voice their opinion on the product of a supranational, deliberative process that had otherwise caused barely a ripple. Hence the convention method of constitutional agency follows an overtly political rather than legal logic, but only in a 
hollowed-out fashion as conventions in their own right have failed to connect with mass politics.

Finally it is necessary to examine the process of constitutional agency as driven by the European Council. As a diplomatic forum for redesigning EU institutions, both this body and the IGCs used to prepare treaty amendments that are infused with intergovernmental power in the shape of national veto points (Tsebelis 2008). However, the particularity of the European Council as a constitutional agent is that its members, individually and collectively, are able to shape (for better or for worse) the politicization of EU constitutional developments. This is because national governments can opt for treaty ratification by referendum as well as seek to avoid contesting rule changes and their actual implementation.

For instance, when the Swedish government put membership of the euro to a referendum in 2003, voters' rejection of joining the final stage of EMU meant that it obtained a de facto opt-out. However, the politicization strategy adopted by a single government may be national in design but can have pan-European effects. Most notably, the story of the pledges to hold referendums on the Constitutional Treaty is one of the contagion effect produced by Tony Blair's decision to hold such a vote when confronted by domestic contestation (Gifford 2010). His idea was to channel EU-related politicization away from the forthcoming election in 2005 so as not to affect his chances of returning to power. The result, however, was for a much broader political debate that saw a further seven countries promise to hold a referendum.

At other times the European Council has sought to coordinate collectively across member states in order to control the way politicization takes place. EU leaders were notably active, for instance, in reminding Irish voters about the benefits of ever closer union in the two episodes in which the Irish government needed to re-run referendums in order to ratify both the Nice and Lisbon Treaties respectively (Hodson and Maher 2014). Indeed, the fact that no other country held a popular vote on the Lisbon Treaty testifies to the way national executives agreed not to politicize this treaty despites its close kinship to the doomed Constitutional Treaty (de Wilde and Zürn 2012). 
Uniquely, therefore, the European Council has certain levers to politicize or depoliticize constitutional change. From a political constitutionalism perspective, this makes constitutional agency via executive discretion stand out from other forms of EU constitutional development. The European Council can - but not necessarily will - link constitutional evolution to partisan mobilization and public debate. Hence when it comes to evaluating the significance of "new intergovernmentalism" in the current dynamics of integration a focus purely on the European Council's impact on the treaties is insufficient. There is an imperative to examine the European Council's ability and willingness to depoliticize or not debates over constitutional development. Its handling of the sovereign debt crisis is a case study in point.

\section{Constitutional Agency and Depoliticization by the European Council during the Eurozone Crisis}

This section analyses how far the intergovernmental approach of the European Council in responding to the Eurozone crisis has involved politicization by this same body. Politicization matters for the normative dimension of political constitutionalism because political contestation (whether conducted through elected representatives or more directly by citizens themselves) is associated with the development of policy and even polity legitimacy (Glencross 2014a; Statham and Trenz 2013). Following de Wilde and Zürn (2012: 140) politicization in this context is defined as the process by which decisions and the institutional procedures behind decision-making become objects of political contestation. The ensuing public and participatory debate is a key step in legitimizing decision-making outcomes by virtue of being able to identify and mobilize some form of majority support.

Hence the European Council's ability to legitimize its own constitutional agency can be assessed by evaluating how explicitly this institution has wanted to subject its emergency decisions to political contestation i.e. politicization. The reality is that throughout the Eurozone crisis the European Council sought to de-politicize its constitutive decisions. In the period 2010-15 the European Council attempted in multiple contexts to depoliticize actions taken to fix the Eurozone crisis. That is, at the same time as heads of state and government took emergency measures, they sought to defuse political contestation surrounding their crisis 
management. Their national electoral legitimacy provided an overweening justification for acting, but democratic political contestation was supposed to play a minimal role in the inter-governmental bargaining behind rescuing EMU. The depoliticization strategy is illustrated here by focusing on a number of instances in which the European Council took a direct interest in how the politics of public finances was conducted in certain member states. In particular, the European Council sought to circumscribe national debates so as to minimize the potential impact of politicization on emergency measures.

The first such episode took place in the second half of 2011, when Greece was dicing with default and borrowing costs for financing Italian public borrowing began approaching unsustainable levels. The worry for the European Council was that contagion from Greece could lead to a debtmanagement problem for the $€ 2$ trillion of Italian debt, which even the combined resources of the Eurozone would be hard-pressed to fix. So when the Greek Prime Minister George Papandreou proposed to politicize domestically the new bailout package being proposed by the "troika" (the European Commission, the ECB, and the IMF), the European Council intervened.

Papandreou's idea - a response to rising discontent within his own party as well as amongst the Greek public over proposed austerity measures was to hold a referendum on the new terms on offer. The announcement of a referendum came on 31 October; within a week Papandreou had resigned and the vote did not go ahead. This policy reversal was in large part due to pressure exercised by the Merkel-Sarkozy tandem claiming to speak for the EU, or at least the Eurozone. The Greek Prime Minister had been summoned to the G-20 summit in Cannes on 3-4 November, where both leaders sought to persuade him to abandon the referendum. Moreover, Papandreou stepped down in favour of a unity government, on the proviso that new elections would be delayed until after the new agreement with the Troika was ratified. The possibility for meaningful Greek domestic contestation of the bailout terms were thus snuffed out as far as possible, the intention being to put in place as quickly as possible measures that would ease market jitters.

In Italy at that same time the situation was different because Prime Minister Silvio Berlusconi was both in a stronger position internally and 
not facing the external intervention of the Troika. Nevertheless, Italy's borrowing costs increased dramatically over the course of 2011, creating a vicious circle of higher interest payments and rising total debt as a percentage of GDP (Lane 2012). EU leaders were particularly concerned about lacking the means to bail out Italy should the country fail to raise debt from private creditors. It was in this context that the Sarkozy-Merkel duo lost faith in Berlusconi's ability to oversee budgetary rigour sufficient to reduce short-term borrowing costs. At a meeting of the European Council in Brussels on 23 October the French and German leaders had already requested revised budgetary proposals from Berlusconi that subsequently failed to convince. This vincolo esterno proved decisive in helping Italian President Giorgio Napolitano to orchestrate the appointment of a technocratic government under the premiership of Mario Monti (Anderson 2014). In doing so, Napolitano ensured that Italian party politics did not jeopardise the European Council's plans to rescue EMU.

These efforts converged in late 2011 around the idea of creating a new treaty mandating enhanced fiscal discipline well beyond the terms of the (already revised and more stringent) Stability and Growth Pact. The key measure was the introduction of national balanced budget rules in order to appease the sentiment in creditor countries that EU bailouts were funding a legacy of public largesse (Glencross 2014a). In keeping with the depoliticization agenda of the preceding months, the European Council, under the aegis of the German government, sought to avoid political contestation of fundamental EMU reform. To this end Angela Merkel was happy for the Fiscal Compact to proceed as an inter-governmental treaty - thereby side-stepping David Cameron's attempt to link favourable concessions to the UK with EU treaty reform (Beach, 2013: 118).

Indeed, the treaty itself was designed to limit politicization of its ratification as it did not require unanimity as a condition of entry into force; it became legally binding when 12 Eurozone countries ratified it, thereby preventing last-minute ratification delays in obstreperous parliaments. In Ireland, the only country that held a referendum on the treaty, depoliticization was evident as the major opposition party supported the government campaign for a yes vote (Hodson and Maher 2014). The Fiscal Compact itself was thus another instance of the depoliticized and intergovernmental approach to reforming EMU in the wake of the sovereign debt crisis. 
But it was in 2015, during the second act of the Greek referendum drama, that the European Council's depoliticization strategy was most evidently laid bare when the new Syriza government organized the referendum on bailout conditionality that Papandreou had only threatened. This attempt to politicize EMU crisis-management meant breaking ranks with their Eurozone counterparts and openly challenging the dominant technocratic, consensus-based approach adopted since the start of the crisis. Ultimately, the price paid for seeking a political deal that did not conform with the negotiation instructions coming from the troika institutions was exclusion. Yanis Varoufakis, the then Greek Finance Minister, was uninvited from a meeting of the "informal" Eurogroup on 27 June 2015 that discussed the impending end of the previous bailout agreement.

Having tried to politicize from within the EU's inter-governmental fora, the Greek government then resorted to direct democracy at the national level. This was not just an appeal for a popular mandate from the Greek people, but was also designed to put debt relief in the public spotlight and engage with anti-austerity politics bubbling away under the surface across Europe. This strategy is consistent with horizontal Europeanization at the grassroots, but the European Council itself was unimpressed and refused to countenance any deal that side-stepped the technical input of the ECB. Consequently, heads of state and government tried to stay aloof from the transnational debate the Greek referendum engendered and refused to acknowledge that a national political mandate could change the negotiation process.

By contrast it was supranational actors, otherwise deprived of a political say in the actual bailout negotiations discussed in the European Council, who entered the fray most publicly. Having already immersed himself in the bailout negotiations with the Greek Prime Minister, Commission President Jean-Claude Juncker made the most dramatic intervention of the referendum campaign with his controversial warning to the Greek people "that you shouldn't choose suicide just because you are afraid of death". Similarly, Martin Schulz, the President of the European Parliament openly expressed his annoyance at Greece's attitude during negotiations. The actions of these supranational actors points to the fact that the new legal-political architecture established by the constitutional agency of the European Council cannot do away with political contestation. As de Wilde 
and Zürn (2012: 150) observe, 'the financial crisis forces the issue of European integration onto the political agenda'.

\section{The Legitimacy Paradox and the Inescapable Politicization of the Eurozone's Economic Order}

It is precisely the European Council's emphasis on de-politicization that has created the legitimacy paradox. That is, while elected heads of state and government draw on their electoral legitimacy to act and reshape EMU, they simultaneously seek to bypass public debate when considered essential for swift resolution. Moreover, this legitimacy paradox is compounded by the European Council's enduring need to draw on the support of supranational actors, who themselves are increasingly at the forefront of politicizing EMU reform. The result is an uneasy tension that is liable to increase because the constitutive changes wrought by the European Council are as much about rule implementation - requiring supranational inputs - as rule change. In this sense, notwithstanding attempts at depoliticizing rule change, the new intergovernmentalism will contribute to the heightened politicization of integration.

This tension is bound to be particularly acute in the future application of the rules contained in the so-called Fiscal Compact and in the new Excessive Deficit Procedure. The feature of the new legal-political architecture that stands out as singularly problematic for the politicization that it will ineluctably generate is the move to a "structural deficit" criterion for both the re-vamped Stability and Growth Pact (SGP) and the Fiscal Compact. This technical-sounding change means that the deficit for each Eurozone country will now be measured by virtue of 'discounting the positive or negative effect that the position on the economic cycle has on the accounts of the exchequer' (Menéndez, 2014: 136). Defining what is the current economic cycle (e.g. global recession) is not the only problem as identifying the actual position on a given cycle - which will need to take into account policy measures such as structural reforms designed to enhance future growth - is also necessary. Hence the very concept of a structural deficit can be considered fundamentally indeterminate (ibid., p. 137).

The indeterminacy of the key metric for enforcing the SGP and the balanced budget provisions of the Fiscal Compact are symptomatic of the 
European Council's reliance on rule-based enforcement. Yet by opting for such a seemingly neutral, technocratic procedure - rather than on an alternative such as market discipline (Kelemen and Teo 2014) - the new intergovernmentalism brings politics back in by the back door. For only a political decision can settle the intense definitional debate regarding the application of criteria that distinguish headline deficits from structural ones.

Resolving this ambiguity, a precondition for identifying compliance and sanctioning non-compliant member states, will from the outset not even be a straightforward inter-governmental affair. Since the European Commission is charged with undertaking an annual review of national fiscal practices it will have to have its say on where each country lies in the supposed economic cycle. Similarly, it is up to the Commission to generate policy recommendations for countries subject to an Excessive Deficit Procedure under the SGP (and even those, namely Germany, running an excess current account surplus), and submit these to the Council and the European Parliament. Hence defining the actual kind of deficit any individual Eurozone country has is bound to be an inherently inter-institutional affair within the EU.

Indeed, this definitional debate is already in full inter-governmental and supranational swing, demonstrating the complex, politicized nature of this specific, ostensibly technical policy detail. François Hollande contested, and won, the French Presidential election in 2012 on a platform advocating a "growth pact" to edulcorate the Fiscal Compact negotiated by his opponent Nicolas Sarkozy. This pledge subsequently gave rise to a European Council summit agreement on 29 June 2012 to launch a "Compact for Growth and Jobs" worth $€ 100$ billion, albeit thanks to some creative accounting.

The French example of politicizing stimulus policies in the face of austerity is part of a nascent EU-pattern that is itself a response to the legitimacy paradox engendered by the European Council's recent constitutional agency. It has already been noted that the institutional response to the Eurozone crisis sparked an unprecedented and sustained level of mobilization around EU issues (Statham and Trenz 2013). What is apparent when viewed through the lens of political constitutionalism is that politicizing rule enforcement is the only means left to contest the fait 
accompli of constitutive changes brought about via the new intergovernmentalism.

More specifically, party leaders and their parties that support Keynesian demand-management chafe at the new economic order of the Eurozone, which is founded on balanced budgets that depend on reducing discretionary (i.e. politically-motivated) spending. This is the context in which the Italian Prime Minister, Matteo Renzi, weighed in after his nomination in 2014. He challenged the budgetary principles of the SGP and the Fiscal Compact by proposing to exclude investment and educational expenditure from public deficit calculations. His argument that such spending boosts growth in the long run, thereby helping to reduce the debt-to-GDP ratio, was a deliberate attempt to politicize the new rules governing EMU. Renzi chose to politicize the issue collectively by associating with Hollande to convene a meeting of eight socialist heads of state in Paris just prior to the June European Council summit. Similarly, the French President for his part sought to exclude costs associated with the government's signature reform plan - a "responsibility pact" of corporate tax breaks designed to boost employment - from figures counting towards the SGP. What these left-of-centre leaders are engaging in, then, is the contestation, on the basis of their national democratic legitimacy, of rule enforcement after the fact of fundamental, intergovernmentally-negotiated and depoliticized rule change.

A further demonstration of the inescapable politicization of the new constitutional arrangements is the participation of supranational actors just as with the bailout deals - in actually contesting the application of the new macro- economic rules. One of Jean-Claude Juncker's first acts as newly-selected President of the European Commission was to promise a change in the Eurozone bailout mechanism so that financial assistance can be provided on the basis of a social impact assessment alongside the existing fiscal sustainability one. In the wake of the migration crisis, the European Commission has indicated a willingness to accept flexibility when monitoring EMU budgetary rules to account for the financial impact of refugee numbers. This proposal comes in the wake of the leniency already afforded France when it comes to the timetable for meeting the EMU rules on annual budget deficits. 
Consequently, it appears that ostensibly depoliticized constitutional developments in the crucial sphere of macro-economic policy are by no means capable of eradicating political contestation and of excluding the participation of supranational actors. It was above all the formal entry into force of these measures that was stage-managed to remove potential opposition from within certain countries, thereby appeasing the markets and the ECB alike (Glencross 2014b). This depoliticization of rule-making is in line with a core assumption of deliberative inter-governmentalism, which states that deliberative processes are a means of insulation from the pressures of the two-level game that usually operates in EU policy debates (Puetter 2012). Yet when it comes to the application of these new rules, politicization and supranational involvement are an inevitable consequence of an ever more Europeanized system of budgetary supervision (Genschel and Jachtenfuchs 2013).

\section{Conclusions}

This article examined the actions and ramifications of the European Council's response to the crisis in EMU governance. The aim was, following the theoretical framework of political constitutionalism, to explore the political dimension of constitutional change. To this end, the article compared the level of political contestation, or politicization, of fundamental changes in the content or interpretation of the treaties, and whether this proceeded by supranational or intergovernmental means. What this comparison demonstrated is that supranational forms of constitutional agency - via judicial intervention or through the convention method - have not offered much by way of institutional opportunities for politicizing integration. By contrast with CJEU jurisprudence or debates in a specially convened constitutional convention, the European Council has at its disposal levers to depoliticize, or not, its own brand of constitutional agency. Most notably, certain heads of government sought to politicize the Constitutional Treaty in their own fashion by calling referendums, with subsequent contagion effects elsewhere. Conversely, a collective agreement was reached to prevent such uncontrolled politicization when it came to the subsequent Lisbon Treaty.

The solutions decided upon by the European Council to fix the sovereign debt crisis were accompanied by a strategy of depoliticization to prevent any domestic contestation that might delay the overhauling of EMU. As 
successful as this intergovernmental strategy was initially, the election of the Syriza government in Greece highlighted the underlying tension surrounding the intergovernmental consensus espoused by the European Council. The willingness of supranational actors to participate in the ensuing political clashes over rule implementation is taken to be symptomatic of how the new intergovernmentalism has Europeanized the politics of macro-economic policy and offers new opportunities for supranational inputs (Genschel and Jachtenfuchs 2013). Moreover, the eventual application of the rules covering member states' structural deficits, combined with nascent debates over how to finance the refugee crisis reveal the impossibility of depoliticizing budgetary politics. Indeed, if the Five Presidents' report, which mooted a common Eurozone treasury, is anything to go by, the next phase of EU constitutional development will coincide with a direct clash over the economic principles of EMU (European Commission 2015).

Ultimately, reading recent EU developments through the lens of political constitutionalism, reveals a paradox behind the constitutional agency of the European Council. Heads of state and government claimed to have the legitimacy to fix EMU and relegate supranational actors to a secondary role. At the same time, however, the European Council sought to dampen down contestation over the constitutionalization of ordo-liberalism. But politicization happened regardless, as shown by contestation in national political arenas (notably in Greece) and by the active participation of supranational actors in debating bailouts. Yet the new economic order established during the Eurozone crisis depends on both the stability of national policy preferences and the supranational enforcement of EMU rules. Hence all the indications are that the new intergovernmentalism will face political contestation in a way that previous, supranational EU constitutional development did not.

\section{REFERENCES}

Alter, K. 1998. Who are the "masters of the treaties"? European governments and the European Court of Justice. International Organization 52, no. 1: 121-47. 
Anderson, P. 2014. The Italian disaster. London Review of Books, 22 May.

Beach, D. 2013. The fiscal compact, euro-reforms, and the challenge for the euro-outs. Danish Foreign Policy Yearbook 2013: 113-33.

Bellamy, R. 2007. Political constitutionalism. Cambridge: Cambridge University Press.

Bellamy, R. and D.Castiglione. 2013. Three models of democracy, political community and representation in the EU. Journal of European Public Policy 20, no. 2: 206-23.

Bickerton, C. J., D. Hodson and U. Puetter. 2014. The new intergovernmentalism: European integration in the post-Maastricht era. Journal of Common Market Studies 53, no.4: 703-22.

Crum, B. 2012. Learning from the EU Constitutional Treaty. London: Routledge.

de Wilde, P. and M. Zürn. 2012. Can the politicization of European integration be reversed? Journal of Common Market Studies 50, s1: 137-53.

de Witte, B. 2003. Entry into force and revision. In Ten Reflections on the Constitutional Treaty for Europe, ed. B de Witte, 203-19. San Domenico di Fiesole: European University Institute).

European Commission. 2015. Completing Europe's Economic and Monetary Union, http://ec.europa.eu/priorities/economic-monetaryunion/docs/5-presidents-report en.pdf (accessed 18 October 2015).

Fabbrini, S. 2007. Compound democracies: why the United States and Europe are becoming similar. Oxford: Oxford University Press. 2013. Intergovernmentalism and its limits: assessing the European Union's answer to the euro crisis. Comparative Political Studies 20, no. 10: 1-27. 
Genschel, P. and M. Jachtenfuchs (2013). Vision vs process: an institutionalist account of the Euro- crisis, paper for the $13^{\text {th }}$ Biennial Conference of the European Union Studies Association, http://euce.org/eusa/2013/papers/5g genschel.pdf (accessed 18 October 2015).

Gifford C. 2010. The UK and the European Union: dimensions of sovereignty and the problem of Eurosceptic Britishness. Parliamentary Affairs 63, no. 2: 321-38.

Glencross, A. 2014a. The absence of political constitutionalism in the EU: three models for enhancing constitutional agency. Journal of European Public Policy 21, no. 8: 1163-80.

2014b. The eurozone crisis as a challenge to democracy and integration in Europe. Orbis: A Journal of World Affairs 58, no. 1: 5568.

Goldoni, M. 2012. Two internal critiques of political constitutionalism. International Journal of Constitutional Law 10, no. 4: 926-49.

Goldoni, M. and C. McCorkindale. 2013. Why we (still) need a revolution. German Law Journal 14, no. 12: 2197-228.

Hodson, D. and I. Maher. 2014. British brinkmanship and Gaelic games: EU treaty ratification in the UK and Ireland from a two-level game perspective. British Journal of Politics and International Relations 16, no. 4: 645-61.

Hooghe, L. and G. Marks. 2009. A postfunctionalist theory of European integration: from permissive consensus to constraining dissensus. British Journal of Political Science 39, no. 1: 1-23.

Kassim, H. 2004. The UK and the Convention on the future of Europe: winning the battle, losing the war. Comparative European Politics 2, no. 3: 261-81. 
Kelemen, D. and T. Teo. 2014. Law, focal points and fiscal discipline in the United States and the European Union. American Political Science Review 108, no. 2: 1-16.

Lane, P. R. 2012. The European sovereign debt crisis. The Journal of Economic Perspectives 26, no. 3: 49-67.

Maatsch, S. 2007. The struggle to control meanings: the French debate on the European Constitution in the mass media. Perspectives on European Politics and Society, 8: 261-80.

MacCormick, N. 1999. Questioning sovereignty: law, state and nation in the European Community. Oxford: Oxford University Press.

Mair, P. 2007. Political opposition and the European Union. Government and Opposition 42, no. 1: 1-17.

Menéndez, A. J. 2014. Editorial: A European Union in constitutional mutation? European Law Journal 20, no. 2: 127-41.

Moravcsik, A. 1998. The choice for Europe: social purpose and state power from Messina to Maastricht. Ithaca: Cornell University Press.

Puetter, U. 2012. Europe's deliberative Intergovernmentalism: the role of the Council and European Council in EU economic governance, Journal of European Public Policy 19, no. 2: 161-78.

Scharpf, F. 2010. The asymmetry of European integration, or why the EU cannot be a "social market economy". Socio-Economic Review 8, no. 2: 211-50.

Statham, P. and H.-J. Trenz. 2013. How European politicization can emerge through contestation: the constitution case. Journal of Common Market Studies 51, no. 5: 965-80. 
Stone Sweet, A. 2004. The judicial construction of Europe. New York: Oxford University Press.

Tsebelis, G. 2008. Thinking about the recent past and the future of the EU: JCMS lecture. Journal of Common Market Studies 46, no. 2: 265-92

Weiler, J. 1991. The transformation of Europe. The Yale Law Journal 100: 2403-83. 